\title{
LIGNINASES PRODUCTION BY BASIDIOMYCETES STRAINS ON LIGNOCELLULOSIC AGRICULTURAL RESIDUES AND THEIR APPLICATION IN THE DECOLORIZATION OF SYNTHETIC DYES
}

\author{
Eleni Gomes $^{1 *}$; Ana Paula Aguiar ${ }^{1}$; Caio César Carvalho ${ }^{1}$; Maricy Raquel B. Bonfá ${ }^{1}$; Roberto da Silva ${ }^{1}$; \\ Mauricio Boscolo ${ }^{1}$ \\ ${ }^{1}$ Universidade Estadual Paulista, Instituto de Biociências, Letras e Ciências Exatas, Laboratório de Bioquímica e Microbiologia \\ Aplicada, São José do Rio Preto, SP, Brasil
}

Submitted: October 19, 2007; Returned to authors for corrections: December 06, 2007; Approved: February 15, 2009.

\begin{abstract}
Wood rotting Basidiomycetes collected in the "Estação Ecológica do Noroeste Paulista", São José do Rio Preto, São Paulo State, Brazil, concerning Aphyllophorales order and identified as Coriolopsis byrsina SXS16, Lentinus strigellus SXS355, Lentinus sp SXS48, Picnoporus sanguineus SXS 43 and Phellinus rimosus SXS47 were tested for ligninases production by solid state fermentation (SSF) using wheat bran or rice straw as culture media. C. byrsina produced the highest laccase $\left(200 \mathrm{U} \mathrm{mL}^{-1}\right)$ and Lentinus sp produced the highest activities of manganese peroxidase $(\mathrm{MnP})$ and lignin peroxidase $(\mathrm{LiP})\left(7\right.$ and $8 \mathrm{U} \mathrm{mL}^{-1}$, respectively), when cultivated on wheat bran. The effect of $\mathrm{N}$ addition on enzyme production was studied in medium containing rice straw and the data showed an increase of 3 up to 4-fold in the laccase production compared to that obtained in SSF on wheat bran. The laccases presented optimum $\mathrm{pH}$ at 3.0-3.5 and were stable at neutral $\mathrm{pH}$ values. Optimum $\mathrm{pH}$ for $\mathrm{MnP}$ and LiP activities was at 3.5 and between 4.5 and 6.0, respectively. All the strains produced laccase with optimum activities between $55-60^{\circ} \mathrm{C}$ while the peroxidases presented maximum activity at temperatures of 30 to $55^{\circ} \mathrm{C}$. The crude enzymes promoted decolorization of chemically different dyes with around $70 \%$ of decolorization of RBBR and cybacron blue $3 \mathrm{GA}$ in $6 \mathrm{~h}$ of treatment. The data indicated that enzymes from these basidiomycetes strains are able to decolorize synthetic dyes.
\end{abstract}

Keywords: laccase, manganese peroxidase, lignin peroxidase, Basidiomycetes, decolorization, synthetic dye

\section{INTRODUCTION}

Basidiomycetes fungi are the most efficient lignin-degrading organisms that produce mainly laccases (EC 1.10.3.2), lignin peroxidase (EC 1.11.10.14) and manganese peroxidase (EC 1.11.1.13). These enzymes present a non-specific biocatalyst mechanism and have been used for bioremediation process due to their ability to degrade azo, heterocyclic, reactive and polymeric dyes $(2,12)$. Prospection for fungi able to secret high levels of lignin-degrading enzymes and novel enzyme variants, with desirable properties for biotechnological applications, is aimed. On the other hand, alternative low cost substrates like agricultural residues for enzyme production using solid state fermentation (SSF) offer economic and environmental advantages.

Around 10 thousand types of synthetic dyes are widely used in the textile, paper, printing and leather tanning industries, corresponding to $8 \times 10^{5}$ tons per year (28). The chemical classes of synthetic dyes mostly used in industrial process are azo, anthraquinone, sulfur, indigoid, triphenylmethyl (trityl) and phthalocyanine derivatives, although other types have many applications such as triazyne (12). Besides the color effect, the

*Corresponding Author. Mailing address: Rua Cristóvão Colombo, 2265, Jd Nazareth, Ibilce/Unesp, Departamento de Biologia, São José do Rio Preto, SP, Brasil, CEP: 15054-000. Phone: +55 017 32212393, Fax: +55 017 32212390. E-mail: eleni@ibilce.unesp.br 
majority of these compounds are toxic, carcinogenic and highly persistent in the environment. Conventional biological treatment of wastewaters is not effective for dyes degradation, so that a number of chemical and physical techniques have been used to remove them, including adsorption to inorganic or organic matrices, decolorization by photocatalysis and oxidation process $(3,4,16)$. However some ligninolytic microorganisms are capable of degrade a wide variety of pollutant substances resembling lignin or its derivative, being is an attractive method due to low cost, specificity and the possibility of a total mineralization of these compounds (32).

In this study, agricultural wastes and industrial by-products were used to evaluate ligninases production by different strains of Basidiomycetes isolated from decaying wood in forests in Brazil and their enzymes were evaluated by decolorizing different synthetic dyes.

\section{MATERIALAND METHODS}

\section{Isolation of microorganisms}

Wood-rotting Basidiomycetes were collected at the "Estação Ecológica do Noroeste Paulista", located between São José do Rio Preto and Mirassol, in the São Paulo State, Brazil. The strains cultures were isolated and purified as described previously (33).

\section{Media, cultivation of fungi and enzyme production}

Pure cultures were tested for production of laccase, manganese peroxidase and lignin peroxidase by solid state fermentation (SSF) in $250 \mathrm{~mL}$ Erlenmeyer flasks containing $5 \mathrm{~g}$ of sterilized wheat bran or $3 \mathrm{~g}$ of rice straw both with approximately $70 \%$ moisture content. Each flask was inoculated with three disks ( $1.5 \mathrm{~cm}$ diameter) of mycelium grown on PDA (potato dextrose agar) medium. The flasks were incubated at $27^{\circ} \mathrm{C}$ for five weeks. The solid fermented material from one Erlenmeyer flask was mixed with $40 \mathrm{~mL}$ distilled water, stirred for $40 \mathrm{~min}$, filtered under vacuum and centrifuged (10 $\mathrm{min}, 20,000 \mathrm{x}$ $\mathrm{g})$. The supernatant was used as the crude enzyme solution.

The effect of nitrogen concentration of the culture media on ligninase production was evaluated using rice straw as media for SSF and by addition of $10 \mathrm{~mL}$ of $\left(\mathrm{NH}_{4}\right)_{2} \mathrm{SO}_{4}$ solution in concentration sufficient to obtain $0.3,1.0,3.0,6.0$ or 21 milligram of $\mathrm{N}$ per gram of solid substrate. The effect of different Nitrogen sources was evaluated by addition of $10 \mathrm{~mL}$ of $\left(\mathrm{NH}_{4}\right)_{2} \mathrm{SO}_{4}$, $\left(\mathrm{NH}_{4}\right)_{2} \mathrm{HPO}_{4}$ or a mixture of $\left(\mathrm{NH}_{4}\right)_{2} \mathrm{HPO}_{4}$ and $\left(\mathrm{NH}_{4}\right)_{2} \mathrm{SO}_{4}$ solutions in concentration necessary to obtain $3 \mathrm{mg}$ of $\mathrm{N}$ per gram of solid substrate (rice straw). The control was carried out using distilled water instead of nutrient solution.

\section{Enzyme assays}

Laccase activity was determined via the oxidation of 2,2'azino-bis(3-ethylbenzthiazoline)-6-sulfonate (ABTS). The reaction mixture, containing $0.1 \mathrm{~mL}$ of $0.3 \mathrm{mM} \mathrm{ABTS}$ in 100
$\mathrm{mM}$ of sodium acetate $(\mathrm{pH} 3.5)$ and $0.1 \mathrm{~mL}$ of crude enzyme solution, was incubated at $40^{\circ} \mathrm{C}$ for $1 \mathrm{~min}$. The ABTS oxidation was monitored by the increase in absorbance at $420 \mathrm{~nm}(\varepsilon$ $=36,000 \mathrm{M}^{-1} \mathrm{~cm}^{-1}$ ). One Unit was defined as $1 \mu \mathrm{mol}$ of ABTS oxidized per minute and activity was expressed in $\mathrm{U}$ per $\mathrm{mL}$ per min (22).

Manganese peroxidase $(\mathrm{MnP})$ was assayed in a mixture of $0.9 \mathrm{~mL}$ of $50 \mathrm{mM}$ of sodium lactate buffer $(\mathrm{pH} 4.0)$ containing 0.3 $\mathrm{mM}$ of manganous ions $\left(\mathrm{Mn}^{2+}\right)$ and $0.1 \mathrm{~mL}$ of crude enzyme solution, at $40^{\circ} \mathrm{C}$. The reaction was started by addition of $40 \mu \mathrm{M}$ $\mathrm{H}_{2} \mathrm{O}_{2}$ and absorbance at $270 \mathrm{~nm}\left(\varepsilon=8100 \mathrm{M}^{-1} \mathrm{~cm}^{-1}\right)$ was monitored (13). One Unit was defined as 1 ìmol complex $\mathrm{Mn}^{+3}$-lactate formed per $\mathrm{mL}$ per min.

Lignin peroxidase (LiP) activity was measured by monitoring the oxidation of veratryl alcohol at $310 \mathrm{~nm}(31)$ at $40^{\circ} \mathrm{C}$. The reaction mixture contained $0.1 \mathrm{~mL}$ of enzyme solution, $0.8 \mathrm{~mL}$ of $2 \mathrm{mM}$ veratryl alcohol in $10 \mathrm{mM}$ sodium acetate $\mathrm{pH} 3.5$. The reaction was started by adding $0.5 \mathrm{~mL}$ of $0.1 \mathrm{mM} \mathrm{H}_{2} \mathrm{O}_{2}$. One Unit was defined as $1 \mu \mathrm{mol}$ of veratraldehyde released per minute using extinction coefficient of $9300 \mathrm{M}^{-1} \mathrm{~cm}^{-1}$.

\section{Enzyme characterization}

The optimum $\mathrm{pH}$ was determined by measuring the activity at $40^{\circ} \mathrm{C}$ in various buffers: sodium-malonate $(\mathrm{pH} 3.0-5.0)$, citratephosphate (pH 5.0-7.0) and tris- $\mathrm{HCl}(\mathrm{pH} 7.0-8.5)$. The optimum temperature was assayed by incubating each reaction mixture at $20-90^{\circ} \mathrm{C}$ in the optimum $\mathrm{pH}$.

The enzymes thermostability was evaluated by incubating the enzymes solutions at various temperatures $\left(10^{\circ} \mathrm{C}-90^{\circ} \mathrm{C}\right)$ for $1 \mathrm{~h}$ at $\mathrm{pH}$ 5.0. An aliquot was withdrawn and placed on ice before assaying for remaining enzyme activity at the optimum $\mathrm{pH}$ and temperature.

The enzyme stability under different $\mathrm{pH}$ values was determined dispersing the crude enzyme $(1: 1)$ in $0.1 \mathrm{M}$ buffer solutions $\mathrm{pH}$ 3.0-5.0 (sodium acetate), $\mathrm{pH}$ 5.0-7.0 (citratephosphate), $\mathrm{pH} 7.0-8.5$ (tris- $\mathrm{HCl}$ ) and pH 8.5-11.0 (glycine- $\mathrm{NaOH}$ ) and maintaining it at $25^{\circ} \mathrm{C}$ for $24 \mathrm{~h}$. An aliquot was used to determine the remaining activity at the optimum $\mathrm{pH}$ and temperature.

\section{Decolorization of synthetic dyes by crude enzyme solution}

Decolorization of dyes was monitored in the mixture containing $0.8 \mathrm{~mL}$ of dye solution, $0.99 \mathrm{~mL}$ of $0.2 \mathrm{M}$ acetate buffer $\mathrm{pH} 3.5,0.1 \mathrm{~mL}$ of crude enzyme and $0.01 \mathrm{~mL}$ of deionized water or ABTS solution (concentration in reactive mixture 0.3 $\mathrm{mM}$ ), at $40^{\circ} \mathrm{C}$. The enzyme solution obtained from SSF on wheat bran for 3 weeks was diluted or concentrated so as to the enzyme activities were around $100 \mathrm{U} \cdot \mathrm{mL}^{-1}$ of laccase and around $5 \mathrm{U} \cdot \mathrm{mL}^{-1}$ for $\mathrm{LiP}$ and $\mathrm{MnP}$.

Visible spectra were recorded using a DU spectrophotometer (BecKman). The rate of decolorization was expressed as the percentage decrease of maximum visible wavelength of 
Table 1. Chemical and structural properties of dyes.

\begin{tabular}{|c|c|c|c|}
\hline Name & Chemical structure & Type & $\begin{array}{c}\lambda \text { of max. } \\
\text { Abs.. }\end{array}$ \\
\hline Azure B & & Triazyne & 645 \\
\hline Orange II & & Azo & 485 \\
\hline Reactive Red 120 & & Azo & 535 \\
\hline Chrysophenine & & Azo & 400 \\
\hline $\begin{array}{c}\text { Remazol Brilhant } \\
\text { Blue R }\end{array}$ & & Antaquinona & 590 \\
\hline $\begin{array}{c}\text { Cybacron blue } \\
\text { 3GA }\end{array}$ & & Triazyne & 600 \\
\hline Methilene blue & & Triazyne & 660 \\
\hline Crystal violet & & Triphenylmethane & 590 \\
\hline
\end{tabular}

Concentration of dyes solutions $\left(\mathrm{mg} \mathrm{l}^{-1}\right)$ Azure $\mathrm{B}=5$ / orange $\mathrm{II}=10$ / Reactive red $=25$, chrysophenine $=10$, remazol brilhant blue $\mathrm{R}=60$, cybacron blue $3 \mathrm{GA}=75$ methylene blue $=7$, crystal violet $=5$. 
absorbance (Table 1). Control tests were conducted with crude enzyme replaced by deionized water. Experiments were performed in triplicate and results were expressed as the mean values.

\section{Chemicals}

Veratryl alcohol and ABTS were purchased from Fluka (Buchs, Switzerland). Synthetic dyes (Table 1) were purchased from Sigma.

\section{RESULTS AND DISCUSSION}

\section{Fungi and ligninases production in SSF}

Seventy-five strains were isolated as pure cultures which were distributed in 7 orders, 17 families, and 42 species of basidiomycetes as presented previously (33). Five strains of white rot of the Aphyllophorales order, Coriolopsis byrsina SXS16 (Polyporaceae), Lentinus strigellus SXS355 and Lentinus sp SXS48 (Lentinaceae), Picnoporus sanguineus SXS 43 (Polyporaceae) and Phellinus rimosus SXS47 (Hymenochaetaceae) were selected for subsequent ligninase production assays.

The highest laccase activity $\left(200 \mathrm{U} \cdot \mathrm{mL}^{-1}\right)$ was obtained from C. byrsina in the $3^{\text {th }}$ week of fermentation in medium containing wheat bran, although a good activity was detected in crude enzyme from $P$. sanguineus in the same medium $\left(93 \cdot \mathrm{U} \cdot \mathrm{mL}^{-1}\right.$ after $3^{\text {th }}$ week) (Fig. 1a). When rice straw was used as substrate, laccase production was lower than in wheat bran for all strains (Fig. 2b). In terms of growth, there was no visible difference in the colonization of the substrates among the strains since all the media were completely colonized by mycelial biomass after two weeks. The laccase activity detected in the culture media was 5 -fold higher than those obtained by Baldrian, Snajdr (2) using SSF of barley bran and wheat bran, respectively.

The Lentinus sp was a good producer of peroxidases $(\mathrm{MnP}$ and LiP) on both substrates (Fig. $1 \mathrm{c}-\mathrm{f}$ ). The values of $\mathrm{MnP}$ and LiP obtained from culture media of $P$. rimosus, $P$. sanguineus and $C$. birsyna were very high compared to those obtained from others fungi such as Pleurotus ostreatus and Trametes versicolor (2,35), T. modesta, T. hirsuta and T. versicolor (24), Phebia tremellosa and Coriolus versicolor (29). In relation to substrate colonization stages, it was observed that the beginning of the fungal growth was associated with peroxidases production while higher laccase activities were detected after $3^{\text {th }}$ week of cultivation. Theses results were opposite of those obtained by Lkounougou et al. (21) with T. versicolor which the laccase expression was observed during the first days of colonization of wood.

The production of the extracellular ligninolytic enzymes is strongly affected by the nature and amount of the nutrients in the substrate, specially nitrogen, and microelements $(5,7,9)$. Agricultural wastes such as wheat bran and rice straw have been used for enhanced ligninase production in submerged and solid state fermentation $(1,25)$. However, data about strict effect of available $\mathrm{N}$ sources in the substrate on extracellular ligninolytic enzyme induction in wood-rotting basidiomycetes have been conflicting. For some species, the ligninolytic enzyme production is suppressed by high nitrogen concentration while for other, high concentration of this nutrient stimulate ligninase production $(14,18-20)$.

In order to valuate the influence of content of available nitrogen in the substrate on ligninase production by the fungi in SSF was carried out assay using the basidiomycetes strains that presented the most homogeneous and fast growth in medium composed by rice straw ( $P$ h. rimosus and $C$. byrsina) and only data about laccase were showed. Different sources and concentrations of this nutrient was added to rice straw since this substrate contained a lower nitrogen concentration $(1.1 \%)$ than wheat bran $(2.4 \%)$ and afforded a rapid growth of the microorganisms but low ligninase activities.

The data in Fig. 2 demonstrate that the laccase production by $P$ h. rimosus and $C$. byrsina was stimulated in concentration until 6 and $3 \mathrm{mg} \cdot \mathrm{g}^{-1}$ respectively, reaching around 4 -fold the activity obtained in the control medium for C. byrsina and 2fold for Ph. rimosus. For both species laccase production was decreased with $21 \mathrm{mg} \cdot \mathrm{g}^{-1}$ of nitrogen. The laccase activity in medium of $C$. byrsina cultivation was higher than that $P h$. rimosus for all $\mathrm{N}$ concentrations, except for $21 \mathrm{mg} \cdot \mathrm{g}^{-1}$.

Laccase production by $C$. byrsina, Ph. rimosus was greatly influenced by type of $\mathrm{N}$ source $\left(3 \mathrm{mg} \cdot \mathrm{g}^{-1}\right)$ (Fig. 3). For the both fungi, the highest enzyme activity was observed in medium on which $\left(\mathrm{NH}_{4}\right)_{2} \mathrm{HPO}_{4}$ was added with a maximum activity of 3.8fold of the control for C. byrsina and 4-fold for Ph. rimosus. The data indicated that $C$. byrsina and Ph. rimosus responded, in terms of laccase induction, mainly the $P$ addition. Although, there was not apparent difference between grown of the fungi in the substrates, the biomass was not quantified and therefore, the stimulation of the grown by $\mathrm{N}$ and $\mathrm{P}$ with consequently higher enzyme production can not to be discarded.

\section{Enzyme characterization}

The laccase activities in the crude filtrates obtained from basidiomycetes cultures were characterized in terms of $\mathrm{pH}$ and temperature optima and stability (Table 2). The laccases produced by all the fungi exhibited maximum activity at $\mathrm{pH} 3.0-$ 3.5 and stability in acidic to alkaline pH. It is common for basidiomycetes laccases $\mathrm{pH}$ optima in the acidic range, although they are more stable at neutral to alkaline $\mathrm{pH}$ values $(23,27,34)$. $\mathrm{pH}$ optimum for $\mathrm{MnP}$ and $\mathrm{LiP}$ activities were variable in function of the strains producer with optimum values between 4.5 to 6.0 for enzymes from C. byrsina and Ph. rimosus.

The laccases showed thermophilic properties with optimum activity at $55-65^{\circ} \mathrm{C}$, similar to thermostable laccases from basidiomycetes strains (POXA1) (17) and from Peniophora sp. 


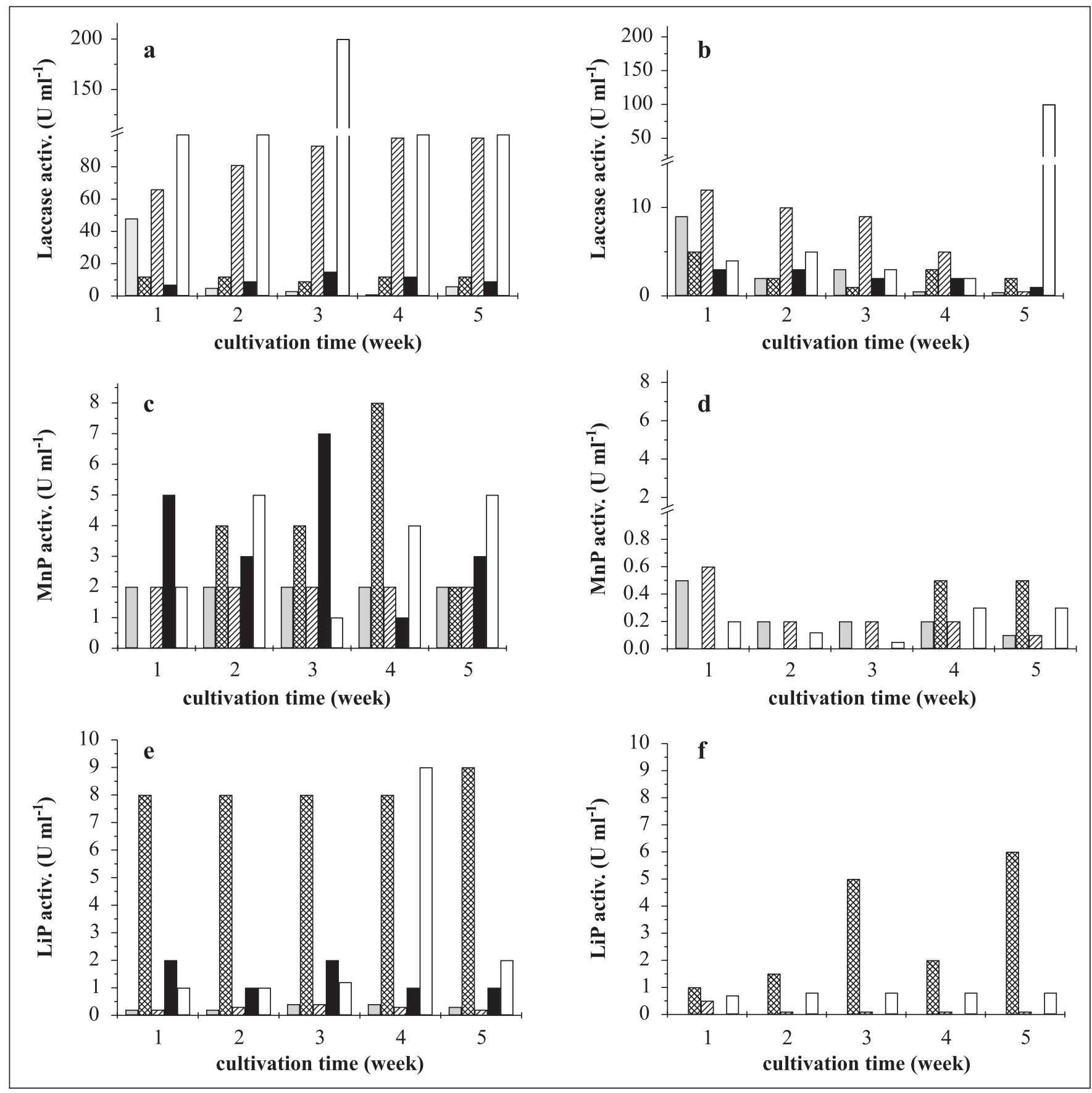

Figure 1. Production of laccase (a,b), MnP (c,d) and Lip (e,f) by solid state fermentation using wheat bran (a,c,e) and rice straw (b,d,f,) as substrate by basidiomycetes strains. Light gray=Lentinus strigellus; $;=$ Lentinus $\mathrm{sp}$; $=$ Picnosporus sanguineus; = Phellinus rimosus; $\square=$ Coriolopsis byrsina .

(19) although they were more sensitive to temperatures above $40^{\circ} \mathrm{C}$ when in absence of substrate when compared to that mentioned laccases.
The maximum peroxidase activities did not exceed $40^{\circ} \mathrm{C}$ but $\mathrm{MnP}$ from majority of strains were stable up to $70^{\circ} \mathrm{C}$ when in absence of substrate. 


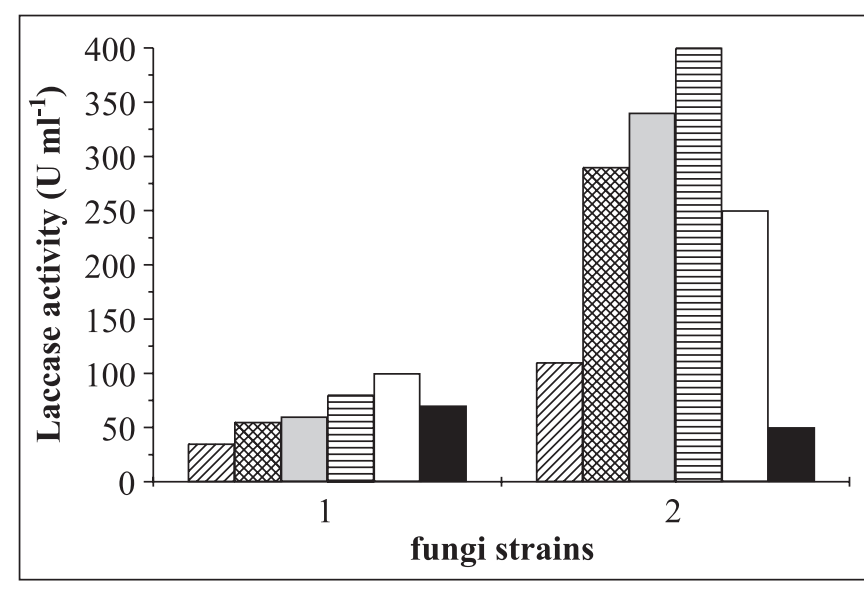

Figure 2. Effect of nitrogen addition on laccase production by Phellinus rimosus (1) and Coriolopsis byrsina (2) in SSF using rice straw as substrate, after 3 weeks of fermentation. Nitrogen addition: $0.3 \mathrm{mg} . \mathrm{g}-1 ; \square 1.0 \mathrm{mg} . \mathrm{g}-1$; $=$ $3.0 \mathrm{mg} . \mathrm{g}-1 ; \square 6.0 \mathrm{mg} . \mathrm{g}-1 ; \square 21.0 \mathrm{mg} . \mathrm{g}-1$.

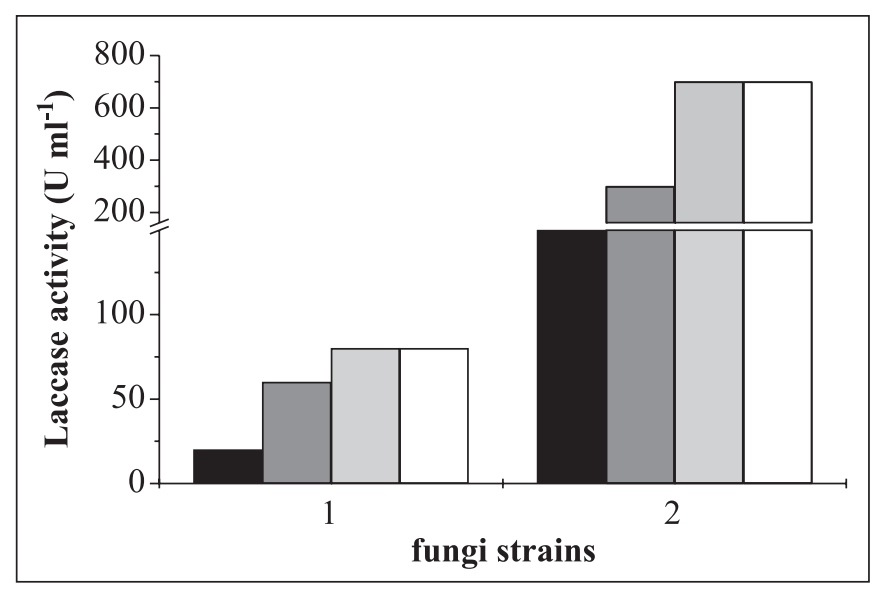

Figure 3. Effect of nitrogen source on laccase production by Phellinus rimosus (1) and Coriolopsis byrsina (2) in SSF using rice straw as substrate, after 3 weeks of fermentation. Nitrogen source $\left(6 \mathrm{mg} \cdot \mathrm{g}^{-1}\right)$ : black $=$ none $($ control $)$; gray $=\left(\mathrm{NH}_{4}\right)_{2} \mathrm{SO}_{4}$; light gray $=\left(\mathrm{NH}_{4}\right)_{2} \mathrm{HPO}_{4} ;$ white $=\left(\mathrm{NH}_{4}\right)_{2} \mathrm{SO}_{4}+\left(\mathrm{NH}_{4}\right)_{2} \mathrm{HPO}_{4}$

Table 2. Biochemical properties of ligninases from basidiomycetes strains.

\begin{tabular}{lcccc}
\hline $\begin{array}{c}\text { Enzyme/ } \\
\text { Microorganism }\end{array}$ & $\begin{array}{c}\text { Optimum } \\
\mathrm{pH}\end{array}$ & $\begin{array}{c}\text { Optimum } \\
\text { temperature }\left({ }^{\circ} \mathrm{C}\right)\end{array}$ & $\begin{array}{c}\mathrm{pH} \text { range preserving } \\
70-100 \% \text { of initial activity }\end{array}$ & $\begin{array}{c}\text { Temperature }\left({ }^{\circ} \mathrm{C}\right) \text { range } \\
\text { preserving } 70-100 \% \text { of initial activity }\end{array}$ \\
\hline Laccase & & & & \\
Lentinus sp. & 3.0 & 65 & $4.0-6.0$ & $10-55$ \\
L. strigellus & 3.5 & $55-60$ & $5.0-11$ & $10-55$ \\
P. sanguineus & 3.0 & $60-70$ & $4.5-11$ & $10-60$ \\
C. byrsina & 3.5 & 60 & $7.5-9.0$ & $10-45$ \\
Ph. rimosus & 3.5 & 60 & $6.0-8.0$ & $10-35$ \\
MnP & & & & \\
Lentinus sp. & $3.5-4.0$ & 55 & $5.0-6.0$ & $10-50$ \\
L. strigellus & 3.0 & 40 & $3.0-10$ & $10-75$ \\
P. sanguineus & 3.5 & 40 & $3.0-11$ & $10-75$ \\
C. byrsina & $4.5-5.0$ & 35 & $7.0-8.0$ & $10-70$ \\
Ph. rimosus & $5.0-6.0$ & 30 & $5.0-7.0$ & \\
LiP & & & & $10-45$ \\
Lentinus sp. & 3.5 & 40 & $5.0-6.0$ & $10-40$ \\
L. strigellus & 3.5 & 40 & $4.5-5.5$ & $10-40$ \\
P. sanguineus & $4.0-4.5$ & 40 & $4.5-6.0$ & $10-70$ \\
C. byrsina & $4.5-5.0$ & 40 & $5.5-7.0$ & $10-70$ \\
Ph. rimosus & $5.0-6.0$ & 30 & $6.0-7.0$ & \\
\hline
\end{tabular}

The important properties observed for crude ligninases were the stability in the large $\mathrm{pH}$ and temperatures range that permits the application of which in several environmental conditions.

\section{Decolorization of synthetic dyes by crude enzymes}

Crude enzymes obtained from cultivation of Lentinus sp., L. strigellus, P. sanguineus and C. bysina on wheat bran for 3 weeks was tested for decolorization of structurally different 
Table 3. Effect of crude ligninases from Basidiomycetes strains on discoloration of synthetic dyes.

\begin{tabular}{|c|c|c|c|c|c|c|c|c|c|c|c|c|c|c|c|c|c|}
\hline \multirow{3}{*}{$\begin{array}{l}\text { Fungi } \\
\text { producer } \\
\text { of enzyme }\end{array}$} & \multirow{3}{*}{ Mediator } & \multicolumn{16}{|c|}{ dyes } \\
\hline & & \multicolumn{2}{|c|}{ Orange II } & \multicolumn{2}{|c|}{$\begin{array}{l}\text { Reactive } \\
\text { Red } 120\end{array}$} & \multicolumn{2}{|c|}{$\begin{array}{l}\text { Chryso } \\
\text { phenine }\end{array}$} & \multicolumn{2}{|c|}{ RBBR } & \multicolumn{2}{|c|}{$\begin{array}{l}\text { Cybacron } \\
\text { blue 3GA }\end{array}$} & \multicolumn{2}{|c|}{ Azure B } & \multicolumn{2}{|c|}{$\begin{array}{l}\text { Methylene } \\
\text { blue }\end{array}$} & \multicolumn{2}{|c|}{$\begin{array}{c}\text { Crystal } \\
\text { violet }\end{array}$} \\
\hline & & $\mathrm{h}$ & $\%$ & $\mathrm{~h}$ & $\%$ & $\mathrm{~h}$ & $\%$ & $\mathrm{~h}$ & $\%$ & $\mathrm{~h}$ & $\%$ & $\mathrm{~h}$ & $\%$ & $\mathrm{~h}$ & $\%$ & $\mathrm{~h}$ & $\%$ \\
\hline Lentinus & ABTS & 48 & 74 & 48 & 27 & 48 & 0 & 48 & 66 & 48 & 66 & 48 & 22 & 48 & 32 & 24 & 65 \\
\hline strigellus & none & 48 & 18 & 48 & 8 & 48 & 0 & 6 & 67 & 6 & 67 & 48 & 0 & 48 & 21 & 48 & 45 \\
\hline Lentinus & ABTS & 48 & 64 & 48 & 0 & 48 & 28 & 48 & 50 & 48 & 50 & 48 & 12 & 48 & 23 & 24 & 39 \\
\hline sp. & none & 48 & 15 & 48 & 0 & 48 & 27 & 6 & 58 & 6 & 58 & 48 & 24 & 48 & 13 & 24 & 51 \\
\hline Picnoporus & ABTS & 6 & 72 & 48 & 0 & 48 & 0 & 48 & 65 & 48 & 65 & 48 & 5 & 48 & 32 & 24 & 50 \\
\hline sanguineus & none & 48 & 40 & 48 & 30 & 48 & 0 & 24 & 75 & 24 & 75 & 48 & 0 & 48 & 0 & 48 & 45 \\
\hline Coriolopsis & ABTS & 48 & 55 & 48 & 8 & 48 & 0 & 48 & 46 & 48 & 46 & 48 & 0 & 48 & 9 & 24 & 45 \\
\hline byrsina & none & 48 & 17 & 48 & 0 & 48 & 0 & 24 & 50 & 24 & 50 & 48 & 19 & 48 & 19 & 24 & 33 \\
\hline
\end{tabular}

$\mathrm{RBBR}=$ Remazol Brilhant Blue R; \% value represents percentage of color reduction in relation to maximum absorbance of dye and the minimal time when this reduction was obtained.

synthetic dyes (Table 1). Table 3 shows the highest percentage of decolorization at the lowest treatment time necessary to obtain it. The data indicated that the enzyme were able to decolorization of different chemical classes of dyes, since efficiently decolorization was observed for orange II, RBBR, cybacron 3GA and crystal violet, which are azo, antraquinone, triazyne and tri methyl methane, respectively. The same results were obtained for enzyme from all the strains tested. Nyanhongo et al. (24) reported similar results in relation to dyes chemical type, such as anthraquinone, azo, indigo and triarymethane, however, these authors observed that crude laccase from different strains presented remarkably difference in their dyes decolorization. These results suggest that the structural chemical complexity of the dyes is more important than the chromophore group type for enzymes actions. High steric impediment of dyes could difficult the electron transference or enzyme approach to reduced substrate. According to Meyer (23), due to the structural variety of azo dyes they are not uniformly susceptible to biodegradation. The substituted groups such as nitro and sulpho are frequently recalcitrant to biodegradation, whereas aromatic substitution 2-methyl, 2methoxy, 2,6-dimethyl and 2,6-dimethoxy-substituted 4-(4sulfophenylazo)-phenol were preferred for azo dyes degradation by peroxidase from Streptomyces spp. and Phanaerochaete chrysosporium (30).

Maximum decolorization for orange II was $74 \%$ in $48 \mathrm{~h}$ using enzyme from $L$. strigellus, although enzyme from $P$. sanguineus decolorized $72 \%$ this dye in $6 \mathrm{~h}$. RBBR and cybacron blue $3 \mathrm{GA}$ lost $75 \%$ of colorization in $48 \mathrm{~h}$ of treatment with enzyme from $P$. sanguineus in absence of ABTS. The maximum decolorization of crystal violet was $65 \%$ in $48 \mathrm{~h}$ of treatment with enzyme from L. strigellus and ABTS. Reactive red 120, chrysophenine, 7azure B and methylene blue were little susceptible to enzymes action.

The presence of ABTS in the reactive mixtures increased the orange II decolorization when enzymes from all fungi were used. RBBR and cybacron 3GA decolorization decreased or was not affected when ABTS was added to reaction mixture depending on the enzyme used. The decolorization of crystal violet increased in presence of ABTS when enzymes from $L$. strigellus, $P$. sanguineus and $C$. byrsina were used and was reduced with enzyme from Lentinus sp.

Since was not used $\mathrm{H}_{2} \mathrm{O}_{2}$, dyes decolorizing can be attributed to the laccase activity and this enzyme was able to oxidize RBBR, cybacron 3GA and crystal violet without mediator participation. Biodegradation of several persistent compounds such as dyes, pesticides and lignin derivatives has been attributed to the oxidative enzymes, mainly laccase $(28,29)$.

The efficiency in terms of time and percentage of decolorization of the anthraquinone and azo-based dyes obtained in this work was higher than those described for enzymes from P. chrysosporium and Pleorotus sajorcaju (6), Dichimitus squalens, Ischnoderma resinosum and $P$. calyptratus (10), Trametes trogii (36), Funalia trigii (26), Pleorotus spp. (11) and similar to obtained by Chulhwan et al. (8). Nevertheless, attempts for better understanding of enzyme attack of theses compounds and their derivative is necessary, since more toxic products might be released.

In conclusion, the white rot fungi grown in SSF using an inexpensive substrate to get high ligninase activity and the high level of synthetic dyes decolorization was achieved in vitro by these crude enzymes. 


\section{ACKNOWLEDGEMENTS}

The authors wish to thank the FAPESP-Fundação de Amparo à Pesquisa do Estado de São Paulo and CNPq Conselho Nacional de Desenvolvimento Científico e Tecnológico for financial support.

\section{RESUMO}

\section{Produção de ligninases por linhagens de fungos Basidiomicetos usando resíduos agrícolas lignocelulósicos e aplicação das enzimas na descoloração de corantes sintéticos}

Fungos decompositores de madeira, do grupo Basidiomicetes, coletados na "Estação Ecológica do Noroeste Paulista", São José do Rio Preto, São Paulo, Brasil, pertencentes a ordem Aphyllophorales e identificados como Coriolopsis byrsina SXS16, Lentinus strigellus SXS355, Lentinus sp. SXS48, Picnoporus sanguineus SXS 43 e Phellinus rimosus SXS47 foram estudados para a produção de ligninases por FES (fermentação em estado sólido) usando farelo de trigo ou palha de arroz como meio de cultura. A espécie $C$. byrsina produziu a maior quantidade de lacase $\left(200 \mathrm{U} \mathrm{mL}^{-1}\right)$ enquanto que Lentinus sp. foi o melhor produtor de manganês peroxidase $(\mathrm{MnP}) \mathrm{e}$ lignina peroxidase ( $\mathrm{LiP})\left(7 \mathrm{e} 8 \mathrm{U} \mathrm{mL}^{-1}\right.$, respectivamente), quando cultivados em meio composto por farelo de trigo. A avaliação do efeito da suplementação de nitrogênio do substrato sólido lignocelulósico (palha de arroz) indicou um aumento de 3 a 4 vezes na produção de lacase. A caracterização das enzimas mostrou que as lacases apresentaram atividade ótima em $\mathrm{pH}$ 3,0-3,5 e foram estáveis em $\mathrm{pH}$ de neutro a alcalino. $\mathrm{O} \mathrm{pH}$ ótimo para atividade de $\mathrm{MnP}$ e LiP foi de 3,5 e entre 4,5 e 6,0, respectivamente. Todas as linhagens produziram lacase com atividade ótima a $55-60^{\circ} \mathrm{C}$, enquanto as peroxidases apresentaram atividades máximas entre temperaturas de 30 e $55^{\circ} \mathrm{C}$. A aplicação das soluções enzimáticas brutas, obtidas pelo cultivo das linhagens em meio de farelo de trigo, em testes de descoloração de corantes sintéticos de diferentes grupos químicos levou a mais $70 \%$ de perda de cor dos corantes RBBR e de cybacron blue $3 \mathrm{GA}$, em $6 \mathrm{~h}$ de tratamento. Os dados obtidos indicaram que as soluções enzimáticas contendo ligninases produzidas pelas linhagens de basidiomicetos estudadas promoveram a descoloração de corantes sintéticos.

Palavras-chave: lacase, manganês peroxidase, lignina peroxidase, Basidiomicetes, descoloração, corantes sintéticos

\section{REFERENCES}

1. Arora, D.S.; Gil, P.K. (2001). Effects of various media and supplements on laccase production by some white rot fungi. Biores. Technol., 77, 89-91.
2. Baldrian, P.; Snajdr, J. (2006). Production of ligninolytic enzymes by litter-decomposing fungi and their ability to decolorize synthetic dyes. Enzyme Microbiol. Technol., 39, 1023-1029.

3. Behnajady, M.A.; Modirshahla, N.; Fathi, H. (2006). Kinetics of decolorization of an azo dye in $\mathrm{UV}$ alone and $\mathrm{UV} / \mathrm{H}_{2} \mathrm{O}_{2}$ processes. $J$. Haz. Mat., 136, 816-821.

4. Bizani, E.; Fytianos, K.; Poulios, I.; Tsiridis, V. (2006). Photocatalytic decolorization and degradation of dye solutions and wastewaters in the presence of titanium dioxide. J. Haz. Mat., 136, 85-94.

5. Buswell, J.K.; Cai, Y.J.; Chang, S.T. (1995). Effect of nutrient nitrogen on manganese peroxidase and laccase production by Lentinula (Lentinus) edodes. FEMS Microbiol. Lett. 128, 81-88.

6. Chagas, E.P.; Durrant, L.R. (2001). Decolorization of azo dyes by Phanaerochaete chrysosporium and Pleurotus sajorcaju. Enzyme Microbial. Technol., 29, 473-477.

7. Chawachart, N.; Khanongnuch, C.; Watanabe, T.; Lumyong, S. (2004.). Rice bran as an efficient substrate for laccase production from thermotolerant basidiomicete Coriolus versicolor strain RC3. Fungal Divers., 15, 23-32,

8. Chulhwan, P.; Lee, Y.; Kim, T-H.; Lee, B.; Lee, J.; Kim, S. (2004). Decolorization of three cid dyes by enzymes from fungal strains. $J$. Microbiol. Biotechnol., 14, 1190-1195.

9. Couto, R.S.; Sanromán, M.A. (2005). Application of solid-state fermentation to ligninolytic enzyme production-Review. Biochem. Eng. J., 22, 211-219.

10. Eichlová I.; Homolka, L.; Lisá, L.; Nerud, F. (2005). Orange G and remazol brilhant blue R decolorization by white rot fungi Dichomitus, Ischnoderma resinosum and Pleurotus calyptratus. Chemosphere, 60, 398-404.

11. Eichlová, I.; Homolka, L.; Lisá, L.; Nerud, F. (2006). Ability of industrial dyes decolorization and ligninolytic enzymes production by different Pleurotus species with special attention on Pleurotus calyptratus, strain CCBAS 461. Process. Biochem., 41, 941-946.

12. Forgacs, E.; Cserháti, T.;Oros, G. (2004). Removal of synthetic dyes from wastewaters: a review. Environ. Intern., 30, 953-971.

13. Glenn J.K.; Akileswarean, L.; Gold, M.H. (1986). Mn(II) oxidation is the principle function of the extracellular Mn-peroxidase from Phanerochaetes chrysosporium. Arch. Biochem. Biophys., 251,6 88-696.

14. Hatvani, N.; Mécs, I. (2002). Effect of the nutrient composition on the dye decolorization and extracellular enzyme production by Lentinus edodes on solid medium. Enzyme Microbial. Techno., 30, 381-386.

15. Hublik, G.; Schinner, F. (2000). Characterization and immobilization of the laccase from Pleurotus ostreatus and its use for the continuous elimination of phenolic pollutants. Enzyme Microbial. Technol., 27, 330-336.

16. Jong Joo, D.; Shin, W.S.; Choi, J-H.; Choi, S.J.; Kim, M-C.; Han M.H.; Ha, T.W.; Kim, Y-H. (2007). Decolorization of reactive dyes using inorganic coagulants and synthetic polymer. Dyes Pigm., 73, 59-64.

17. Jordaan, J.; Pletschke, B.I.; Leukes, W.D. (2004). Purification and partial characterization of a thermostable laccase from an unidentified basidiomycete. Enzyme Microbial. Technol., 34, 635-641.

18. Kaal, E.E.J.; Field, J.A.; Joice, T.W. (1995). Increasing ligninolytic enzyme activities in several white-rot basidiomycetes by nitrogensufficient media. Biores. Technol., 53, 133-139.

19. Keyser, P.; Kirk, T.K.; Zeikus, J.G. (1978). Ligininolytic enzyme systems of Phanaerochaetes chrysosporum synthetized in the absence of lignin in response to N starvation. J. Bacteriol., 135, 790-797.

20. Leatham, G.F.; Kirk, T.K. (1983). Regulation of ligninolytic activity by nutrient $\mathrm{N}$ in white-rot basidiomycetes. FEMS Microbiol. Lett., $16,65-67$.

21. Lekoounougou, S.; Mounguengui, S.; Dumarçay, S.; Rose, C.; Courty, P.E.; Garbaye, J.; Gérardin, P.; Jacquiot, J.P.; Gelhaye, E. (2007). Initial stages of Fagus sylvatica wood colonization by the white-rot 
basidiomycete Trametes versicolor: Enzymatic characterization. Intern. Biodeg. Biodet., in press- doi:10.1016/j.ibiod.2007.06.013.

22. Machado, K.M.G.; Matheus, D.R. (2006). Biodegradation of remazol brilhant blue R by ligninolytic enzymatic complex produced by Pleurotus ostreatus. Braz. J. Microbiol., 37, 468-473.

23. Meyer, U. (1981). Biodegradation of synthetic organic colorants. FEMS Symp., 12, 371-385.

24. Niku-Paavola, M.L.; Fagerström, K.; Kruus, K.; Viikari, L. (2004) Thermostable laccases produced by a white-rot fungus from Peniophora species. Enzyme Microbial. Technol., 35, 100-102.

25. Nyanhongo, G.S.; Gomes, J.; Gübitz, G.M.; Zvauya, R.; Read, R.; Steiner, W. (2002). Decolorization of textile dyes by laccases from newly isolated strain of Trametes modesta. Water Res., 36,1449-1456.

26. Park, C.; Lee, M.; Kim, S-W.; Chase, H.A.; Lee, J.; Kim, S. (2007). Biodegradation and biosorption for decolorization of synthetic dyes by Funalia trogii. Biochem Eng J (in press - available online at www.sciencedirect.com).

27. Périé, F.H.; Reddy, B.V.; Blakburn, N.J.; Gold, M.H. (1998). Purification and characterization of laccases from the white-rot Basidiomycete Dichomitus squalens. Arch. Biochem. Biophys. 353, 349-355.

28. Revankar, M.S.; Lele, S.S. (2007). Synthetic dye decolorization by white rot fungus, Ganoderma sp WR-1. Biores. Technol., 98,7 75780 .

29. Robinson, T.; Chandran, B.; Nigam, P. (2001). Studies on the production of enzymes by white-rot fungi for the decolorization of textile dyes. Enzyme Microbiol. Technol., 29, 575-579.
30. Suzuki, T.; Timofei, S.; Kurunczi, L.; Dietze, U.; Schüürmann, G. (2001). Correlation of aerobic biodegradability of sulfonated azo dyes with the chemical structure. Chemosphere, 45: 1-9.

31. Tien, M.; Kirk, K.T. (1988). Lignin peroxidase of Phanerochaetes chrysosporium. In: Wood, K.; Kellogg, S.T. Methods Enzymol., 161, part B, 238-249.

32. Van der Zee, F.P.; Villaverde, S. (2005). Combined anaerobic-aerobic treatment of azo dyes-azo dyes. A short review of reactor studies. Water Res., 39, 1425-1440.

33. Xavier-Santos, S.; Carvalho, C.C.; Bonfá, M.R.B.; Silva, R.; Capelari, M.; Gomes, E. (2003). Screening for pectinolytic activity of woodyrotting Basidiomycetes and characterization of the enzymes. Folia Microbiol., 48, 1-8.

34. Xu, F; Shin; Brwn, W.S; Wableithner, J.A.; Sundaram, I.J.M.; Solomon, F.I. (1996). A study of a series of recombinant fungal laccases and bilirubin oxidase that exhibit significant differences in redox potential, substrate specificity, and stability. Biochem. Biophys. Acta., 1292, 303-311.

35. Yuri, L.; Park, C.; Lee, H.C.; Kim, T-H.; Lee, J.; Kim, S. (2006) Effect of nutrients on the production of extracellular enzymes for decolorization of reactive blue 19 and reactive black 5. J. Microbiol. Biotechnol., 16, 226-231.

36. Zouari-Mechini, H.; Mechini, T.; Dhouib, A.; Sayadi, S.; Martínez, A.T.; Martínez, M.J. (2000). Laccase purification and characterization from Trametes trogii isolated in Tunisia: decolorization of textile dyes by the purified enzyme. Enzyme Microbial Technol., 39, 141148. 